\title{
Strategies for Adopting Building Information Modeling (BIM) in Sustainable Building Projects-A Case of Malaysia
}

\author{
Bilal Manzoor ${ }^{1}$, Idris Othman ${ }^{1}$ (D), Syed Shujaa Safdar Gardezi ${ }^{2}$ and Ehsan Harirchian ${ }^{3, *(D)}$ \\ 1 Department of Civil \& Environmental Engineering, University Technology PETRONAS, \\ Seri Iskandar 32610, Malaysia; bilal_18003504@utp.edu.my (B.M.); idris_othman@utp.edu.my (I.O.) \\ 2 Department of Civil Engineering, Capital University of Science and Technology (CUST), \\ Islamabad 44000, Pakistan; dr.shujaasafdar@cust.edu.pk \\ 3 Institute of Structural Mechanics (ISM), Bauhaus-Universität Weimar, 99423 Weimar, Germany \\ * Correspondence: ehsan.harirchian@uni-weimar.de
}

\section{check for} updates

Citation: Manzoor, B.; Othman, I.; Gardezi, S.S.S.; Harirchian, E Strategies for Adopting Building Information Modeling (BIM) in Sustainable Building Projects-A Case of Malaysia. Buildings 2021, 11, 249. https://doi.org/10.3390/ buildings 11060249

Academic Editors: Henry Abanda, Blaise Mempouo and Lucio Soibelman

Received: 20 April 2021

Accepted: 7 June 2021

Published: 10 June 2021

Publisher's Note: MDPI stays neutral with regard to jurisdictional claims in published maps and institutional affiliations.

Copyright: (c) 2021 by the authors. Licensee MDPI, Basel, Switzerland. This article is an open access article distributed under the terms and conditions of the Creative Commons Attribution (CC BY) license (https:// creativecommons.org/licenses/by/ $4.0 /)$.

\begin{abstract}
In terms of sustainable growth, Malaysia's construction industry faces significant challenges, such as construction costs and lack of awareness. To meet these challenges, it is essential to integrate building information modeling (BIM) and sustainable development. As a result, this study aimed to establish strategies for adopting BIM in sustainable building projects. A systematic literature review was performed to classify the strategies to accomplish this aim, followed by a questionnaire survey of 129 construction project stakeholders. Mean score and exploratory factor analysis (EFA) were conducted to explore the detailed influence of BIM adoption strategies in sustainable building projects. The results revealed that "workshops, lectures, and conference events are used to enhance public awareness" and "better information on the costs and benefits of sustainable materials" and "strengthened sustainable development" were the most essential strategies to boost sustainable growth in building projects. Furthermore, EFA was conducted to undertake the group analysis, namely, to identify the standardization-related strategy, economic-related strategy, awareness-related strategy, and environment-related strategy. This study paves the way for future scholars, policymakers, and practitioners to investigate the limitations of future studies.
\end{abstract}

Keywords: building information modeling; sustainable building; projects; strategies; construction

\section{Introduction}

Malaysia's construction boom began in the early 1990s, with the completion of megaprojects, such as the PETRONAS Twin Towers and the Malaysian Skyscraper Development Corporation. The construction industry peaked in 1995 when its GDP surged by an astounding 17.3 percent [1]. This rate of development was comparable to that of developed countries. The GDP of the construction industry increased at a 14 percent annual pace from 1994 to 1997. As a result, when the Asian Financial Crisis hit Malaysia and the Asian region in 1998, the Malaysian construction industry found itself in an even more hazardous situation [2]. However, throughout time, the government has provided the majority of the funding for the Malaysian construction industry in order to assist in the creation of the country's infrastructure [3]. Furthermore, the Malaysian government plans to transform Malaysia into a nation with sustainable growth by 2030. However, in terms of sustainable growth, Malaysia's construction industry has substantial hurdles to overcome, such as building costs and a lack of awareness [4]. Given the current market conditions, enhancing productivity and quality is critical for establishing a long-term viable local construction sector that is capable of capitalizing on worldwide opportunities regarding governing the life cycle of buildings.

Building information modeling (BIM) may act as a central database that aids in the entire process of managing the building life cycle by making digital representations of the physical and functional information of sustainable projects available to all stakeholders. 
It has enabled the digital management of the full life cycle of buildings, including the design, construction, operation, management, and maintenance phases of sustainable projects, resulting in a significant improvement in project productivity and cost control, while lowering the risks associated with such projects [5]. BIM models, for example, can be used in advance to determine the necessary construction supplies, equipment, and capital requirements, as well as to conduct schedule planning in sustainable projects [6]. BIM may also be used to track work in real time, estimate costs, identify construction deviations, check construction quality, record product problems, and restore projects on time. Green building designers, builders, and operators can benefit from BIM to improve the design, construction, and management of green buildings [7]. This analytics tool can be used to study the numerous functions of green buildings, such as energy use, carbon emissions, and ventilation assessments, in order to promote building sustainability.

The construction industry benefits society in ways other than profit, health, and wellbeing. It has significant effects on community services while enhancing individuals' quality of life [8] and safety [9]. The government has a ready supply of public infrastructure in the construction sector that it can offer to the country. As a result of growing concern that human activities are having a major negative impact on the environment, sustainability has become a mainstream paradigm in the construction industry [10]. Today's generally agreed concept of sustainability is that of the World Commission on Environment and Development (WCED), which describes sustainable development as "development that meets the needs of the present without compromising future generations' ability to meet their own needs" [11]. As a result, when carrying out building projects, caution must be taken not to deplete the available capital to the extent that future generations will be unable to meet their own needs.

The sustainable construction process seeks to promote the natural environment while also ensuring protection, increasing human dignity, and fostering economic justice, which is very much in the spirit of the values and purpose of those views [12]. It combines the fundamental themes of sustainable development and aims to instill environmental accountability, social awareness, and economic profitability in key players creating the built environment [13]. Thus, sustainability in construction can be described as a method of striking a balance between economic, environmental, and social factors regarding building design, construction, usage, and maintenance [14]. However, research has shown that the degree of sustainability in the majority of developing countries is low [15].

Abolore [16] linked the low degree of sustainability of building projects to participants' lack of understanding of the idea of sustainability. Jamaludin et al. [17] made a similar discovery when analyzing the awareness, drivers, attitudes, and barriers of sustainable construction. It was found that the level of sustainable construction implementation was poor and this may be attributable to the relative unfamiliarity of people with the idea. However, according to Durdyev et al. [18], the major challenge regarding sustainability implementation is not one of understanding, but one of appropriateness. While sustainability is recognized, it is not followed correctly due to financial constraints, an uneconomical construction project, or the issue of sustainable resource management, which is overlooked given that comprehensive nature of sustainable construction is a difficult task when applied to achieve the desired goals [19].

Yap et al. [20] asserted in an analysis of sustainable construction in developing countries that one major challenge is that it is viewed as a term that would add costs to the project. It has been found that additional costs for construction projects and limited knowledge of the advantages of sustainable construction are the main challenges [21,22]. According to Ahmad et al. [23], the fear of higher investment costs for sustainable buildings relative to conventional buildings, as well as the possibility of unexpected costs, are frequently cited as challenges for sustainable buildings. Ahmad et al. [23] found that monitoring, controlling, practical schedules, problem-solving capacity, project goal comprehension, and resource allocation are critical for ensuring the success of sustainable construction. Based on this theoretical background, this study assessed the adoption of BIM in sustainable 
building projects. It is pertinent to mention that the construction sector under discussion remains in its very basic stage regarding the implementation of BIM. One of the challenges lies in considering the proper strategic directions to promote the application of BIM in sustainable developments. This is why the basic concern at the strategic level has been addressed in the current study.

\section{Literature Review}

Stakeholder collaborations will help to improve the overall performance of sustainable building practices by resolving challenges that the owners, public, clients, and consumers face [24]. By providing an online forum for people to work on, BIM can make building life much more effective than conventional methods, enabling them to easily switch from designs to implementation to post-design to maintenance [25,26]. BIM adds a level of usefulness to the design that allows it to be used to solve problems while also contributing to environmental sustainability $[27,28]$. With this intelligent BIM model, an entire building performance analysis can be performed, performance effects can be observed, an appearance simulation can be run, and a visualization of the building can be presented [28].

Although it can be used in a variety of fields, BIM is ideally suited for sustainable building projects and applications that need data on sustainability and energy efficiency [28]. This is a method of making improvements that are beneficial to long-term environmental sustainability. Previous research has shown that using BIM technology plays an important role in waste reduction, which is an important feature of a sustainable project. Curry et al. [29] suggested the convergence of BIM and LCA was based on a life cycle cost assessment. Bynum et al. [30] studied sustainable design applications to various scenarios and applications, including by architects and developers, prior to understanding the perceptions applied to applying BIM, especially as part of sustainable construction. Kota et al. [31] investigated the use of BIM for quantifying day lighting within sustainable buildings based on analyses and simulations of day-lighting models.

It is vital to conduct further research in order to have a better understanding of strategies to adopt BIM in sustainable building projects in Malaysia. Previous research did not thoroughly discuss these strategies; however, these strategies must be carefully considered in order to establish and adopt successful initiatives for improving BIM technology usage in sustainable building projects. This study identified these strategies and examined their effect on sustainable building projects of Malaysia. From an extensive literature review, the following strategies were highlighted, as shown in Table 1.

Table 1. Strategies used to adopt BIM in sustainable building projects.

\begin{tabular}{|c|c|}
\hline Strategies & References \\
\hline Efficient energy forecasts in sustainable buildings & [32] \\
\hline Prompting construction industry standards & [33] \\
\hline More research on BIM toward sustainable buildings & [34] \\
\hline Improvements in BIM application standards in sustainable buildings & [35] \\
\hline Economic and additional financial BIM adoption rewards & [36] \\
\hline Enhance social networking (e.g., print media, internet, and radio and television programs) & [37] \\
\hline Strengthened sustainable development & [38] \\
\hline Workshops, lectures, and conference events are used to enhance public awareness & [39] \\
\hline Overall support from the senior management & [40] \\
\hline Acknowledging and supporting BIM experts & [41] \\
\hline Better information on the costs and benefits of sustainable materials & [42] \\
\hline Compel strict environmental controls and assessments & [43] \\
\hline System of green or environmentally friendly labeling & [44] \\
\hline
\end{tabular}




\section{BIM and Sustainability}

BIM has changed the way sustainable building projects are undertaken [45]. Constructions can be evaluated using BIM to determine their advantages and disadvantages, as well as their opportunities, while accounting for other factors, such as financial, technical, and environmental aspects [46]. It is believed that BIM has the potential to help the construction industry and that widespread adoption could have a significant effect on sustainability [47]. The term "BIM," which could be used to describe this process, means "elaborate an integrated and holistic building strategy" that includes design, construction, and operational aspects, as well as the use of modeling [48]. A significant concern in building-oriented designs and implementation methods is ensuring that construction does not deplete natural resources [49]. These things were shown to be beneficial in achieving a proper balance of the two goals, namely, reducing the environmental effect and streamlining construction procedures, through creativity and application of these advanced technologies to the construction industry regulation of energy conservation [50].

Sustainable development is beneficial in all aspects of building projects when incorporating BIM [51]. This involves the development and application of long-term strategies, as well as modern, cutting-edge technology. Sustainable building projects, as an advanced building type, are attracting worldwide attention [52]. According to the researchers at Osaka University in Japan, the "sustainable architecture" plan was first implemented in their research facility. The buildings are surrounded by a green yard and a fresh-looking wall, which greatly decreases their energy costs [53]. As a result, builders, architects, and designers are exploring new building design models that fit people and the environment during the planning, construction, usage, and maintenance as much as possible [54]. Such sustainable practices and innovations will generate enormous profits as a result of reduced carbon dioxide $\left(\mathrm{CO}_{2}\right)$ emissions and increased energy efficiency, as well as being more environmentally friendly. It is credited with promoting resource management and protecting workers' safety during construction, resulting in less waste and fewer people being exposed to risks [55].

BIM technology is gaining popularity due to its model-based characteristics and the technology for coordinating the use of building expertise [56]. BIM has many benefits owing to its integration of expertise from design and project participants, which include improving the design efficiency, reducing construction costs, and promoting the sustainability of projects while ensuring that project workers are interconnected and contributing toward accelerating projects and help to maximize project activities [57]. In terms of practical use, real BIM technology ventures are widely used in Western countries. Despite widespread acceptance, there is strong evidence that BIM adoption and innovation have helped sustainable growth in both the United States and Europe [58]. According to the U.S. National BIM standard, BIM adoption increased from 13 to $48 \%$ between 2010 and 2014 [59]. BIM refers to representative approaches to streamlining sustainability processes in which one can define and handle the various components that comprise a system, as well as anticipate and enhance its capacity [60].

BIM aids both project participants and beneficiaries in realizing various benefits in sustainable development [61]. A flow system can easily generate and project information on energy use while still providing accurate work data during the construction project. BIM provides an information and communication technology (ICT) system that encourages collaboration between stakeholders across the life cycle of sustainable projects; this makes it simple to input, extract, share, or transform information in the BIM platform [62]. The most challenging task for sustainable buildings is the inability to collect life cycle data, track projects, and perform real-time data analysis to share with project participants [63]. Despite these limitations, the substantial progress that has been made in the use of BIM technology and sustainable building projects are able to achieve positive results by taking into account these new features [64]. 


\section{Research Methodology}

In the research methodology, there were three stages. In the first stage, data were collected from the literature by identifying BIM adoption strategies and developing a questionnaire survey to be distributed to stakeholders (contractors, clients, and consultants). In the second stage, the SPSS 22.0 software package was used to evaluate the respondents' feedback and undertake data analysis, such as demographic analysis of the questionnaire respondents, convergent validity, Spearman's rank correlation coefficient, mean score analysis, and exploratory factor analysis (EFA). In the third and final stage, a discussion was carried out on the basis of the analysis results. The research methodology flowchart is shown in Figure 1.
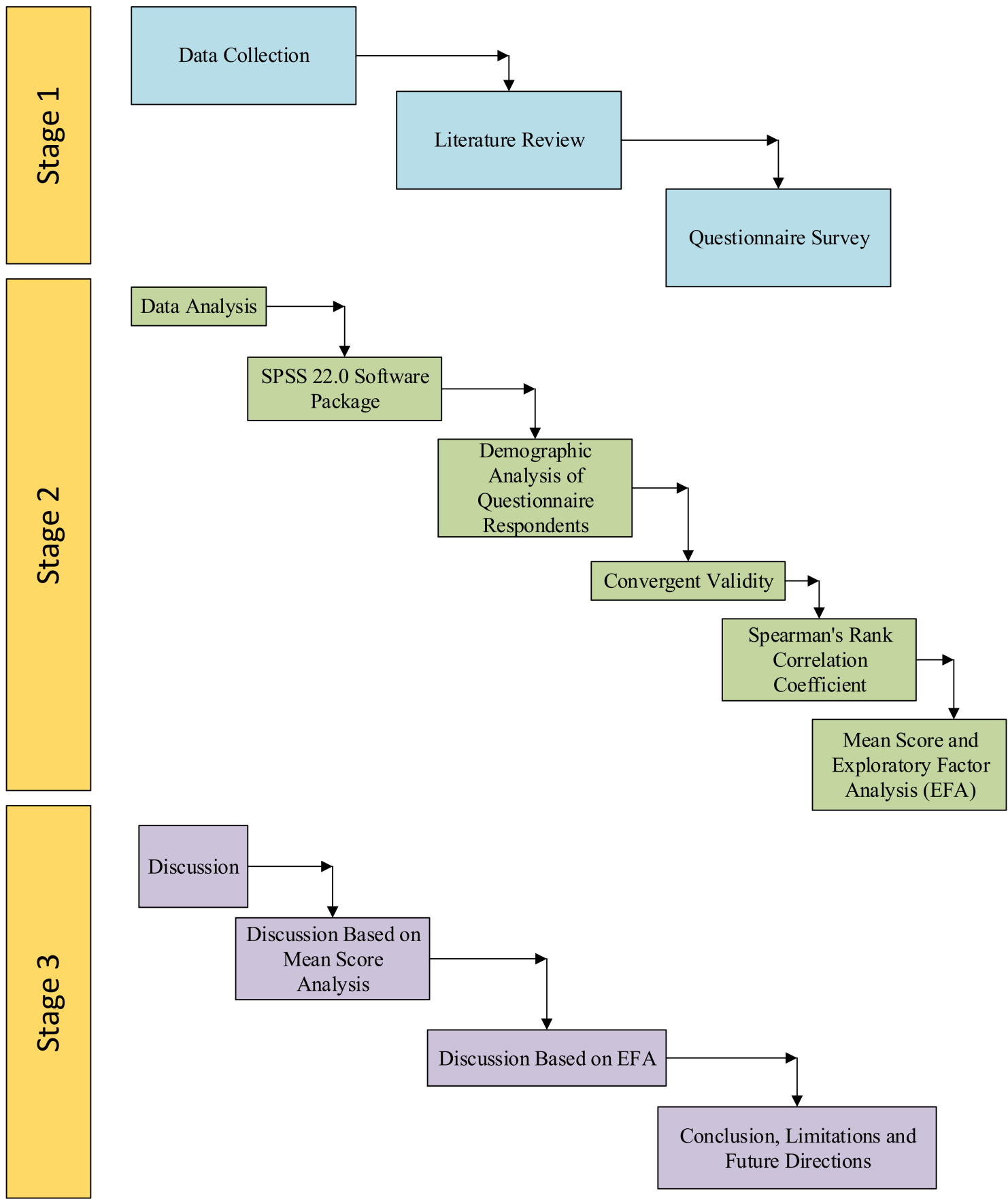

Figure 1. Research flowchart design. 


\section{Questionnaire Design and Survey}

A semi-structured interview was conducted prior to the final questionnaire survey. The final questionnaire was developed using a literature review, as well as input from the semi-structured interviews. The aim of these semi-structured interviews was to determine the relevance and completeness of the questionnaire data. Two assistant professors, two professors, and one postgraduate student took part in semi-structured interviews. The final questionnaire was divided into two sections: (a) general information about the respondents and (b) strategies used to adopt BIM into sustainable building projects using a Likert scale (1-strongly disagree, 2-disagree, 3-moderately, 4-agree, 5-strongly agree). In addition, 250 questionnaires were distributed via e-mail with 129 responses, yielding a response rate of $51 \%$. The questionnaire was distributed in the northern region of Malaysia. The respondents were chosen based on their work experiences in the fields of BIM and sustainability, as well as their understanding of BIM and their depth of knowledge.

\section{Results Analysis}

This section explores the results of the demographic analysis of questionnaire respondents, convergent validity, Spearman's rank correlation coefficient, mean score analysis, and EFA in detail.

\subsection{Demographic Analysis of Questionnaire Respondents}

The questionnaire survey respondents were categorized based on their gender, education qualification, working experience, construction projects' stakeholders, and position of stakeholders. Table 2 elaborates the distribution of respondents.

Table 2. Distribution of respondents.

\begin{tabular}{cccc}
\hline \multirow{2}{*}{ Item } & Description & $\begin{array}{c}\text { Number of } \\
\text { Participants }\end{array}$ & Percentage (\%) \\
\hline \multirow{2}{*}{ Gender } & Male & 101 & 78 \\
& Female & 28 & 22 \\
\hline \multirow{3}{*}{ Educational qualification } & Bachelors & 32 & 35 \\
& Masters & 29 & 25 \\
& PhD & 45 & 22 \\
& Professional engineers & 23 & 18 \\
Working experience & 5-7 years & 55 & 45 \\
& 8-9 years & 36 & 35 \\
\hline \multirow{2}{*}{ Construction projects' } & More than 10 years & 38 & 20 \\
stakeholders & Contractors & 56 & 43 \\
& Clients & 26 & 37 \\
Position of stakeholders & Consultants & 47 & 20 \\
& Quantity surveyor & 45 & 38 \\
& Construction manager & 45 & 27 \\
\hline
\end{tabular}

\subsection{Convergent Validity}

The degree of accuracy within the measurement result was used to assess the reliability. This analysis was able to assess the data's reliability by using SPSS 22.0. It also produced a Cronbach's alpha coefficient, which is a popular method of determining data validity. The Cronbach's alpha coefficient usually has a value between 0.6 and 0.8 ; if it has a value higher than 0.8 , it is the most reliable [65]. The analysis for this study yielded a reliability coefficient value of 0.912 , indicating a very high degree of data reliability. 


\subsection{Spearman's Rank Correlation Coefficient}

The Spearman's rank correlation coefficient $\left(r_{s}\right)$ is calculated using the following equation [66]:

$$
r_{s}=1-\left[6 \sum_{\mathrm{n}=1}^{5} \frac{\left(\mathrm{d}^{2}\right)}{\mathrm{n}\left(\mathrm{n}^{2}-1\right)}\right]
$$

where $r_{s}=$ Spearman's rank correlation coefficient;

$\mathrm{d}=$ the difference between ranks assigned to items;

$\mathrm{n}=$ the number of respondents.

The Spearman's rank correlation coefficients were calculated for all stakeholders. The consultants and contractors had a coefficient value of 0.890 . The correlation between clients and consultants was 0.813 , while the correlation between clients and contractors was 0.841 . Furthermore, there was a substantial relationship between the three stakeholders $p=0.000$ which was less than the allowable sum of significance of 0.01 . In other words, a deep relationship between consultants and contractors, or to put it another way, a long, intimate bond between clients and consultants.

\subsection{Mean Score Analysis}

The aim of mean score analysis is to rank the relative importance of factors in a quantitative analysis. Mean score analysis was also used in various previous studies $[67,68]$. The rankings of BIM adoption strategies were categorized into four parts with the data analysis results using mean values: (a) overall ranking, (b) ranking according to contractors' perspectives, (c) ranking according to consultants' perspectives, and (d) ranking according to clients' perspectives. Table 3 illustrates the detailed picture of the mean score analysis.

Table 3. Mean score analysis of respondents.

\begin{tabular}{|c|c|c|c|c|c|c|c|c|}
\hline \multirow{2}{*}{ Strategies } & \multicolumn{2}{|c|}{$\begin{array}{c}\text { Overall } \\
\text { Respondents }\end{array}$} & \multicolumn{2}{|c|}{$\begin{array}{l}\text { Contractors' } \\
\text { Perspectives }\end{array}$} & \multicolumn{2}{|c|}{$\begin{array}{l}\text { Consultants' } \\
\text { Perspectives }\end{array}$} & \multicolumn{2}{|c|}{$\begin{array}{c}\text { Clients' } \\
\text { Perspectives }\end{array}$} \\
\hline & $\begin{array}{l}\text { Mean } \\
\text { Value }\end{array}$ & Rank & $\begin{array}{l}\text { Mean } \\
\text { Value }\end{array}$ & Rank & $\begin{array}{l}\text { Mean } \\
\text { Value }\end{array}$ & Rank & $\begin{array}{l}\text { Mean } \\
\text { Value }\end{array}$ & Rank \\
\hline $\begin{array}{c}\text { Workshops, lectures, and conference events are used to } \\
\text { enhance public awareness }\end{array}$ & 4.10 & 1 & 4.02 & 2 & 4.09 & 2 & 4.00 & 1 \\
\hline $\begin{array}{l}\text { Better information on the cost and benefits of } \\
\text { sustainable materials }\end{array}$ & 3.99 & 2 & 3.90 & 1 & 3.89 & 1 & 3.85 & 3 \\
\hline Strengthened sustainable development & 3.80 & 3 & 3.81 & 3 & 3.82 & 4 & 3.72 & 2 \\
\hline System of green or environmentally friendly labelling & 3.82 & 4 & 3.75 & 4 & 3.71 & 3 & 3.67 & 12 \\
\hline Overall support from the senior management & 3.64 & 5 & 3.66 & 6 & 3.33 & 5 & 3.50 & 4 \\
\hline Acknowledging and supporting BIM experts & 3.60 & 6 & 3.40 & 5 & 3.20 & 6 & 3.41 & 5 \\
\hline $\begin{array}{l}\text { Economic and additional financial BIM } \\
\text { adoption rewards }\end{array}$ & 3.07 & 7 & 3.12 & 7 & 3.11 & 7 & 3.29 & 6 \\
\hline Compel strict environmental controls and assessments & 2.96 & 8 & 2.90 & 13 & 2.99 & 10 & 3.01 & 7 \\
\hline Prompting construction industry standards & 2.87 & 9 & 2.85 & 8 & 2.82 & 9 & 2.80 & 10 \\
\hline $\begin{array}{c}\text { Enhance social networking (e.g., print media, internet, } \\
\text { and radio and television programs) }\end{array}$ & 2.76 & 10 & 2.71 & 12 & 2.69 & 8 & 2.75 & 13 \\
\hline More research on BIM toward sustainable buildings & 2.70 & 11 & 2.60 & 10 & 2.58 & 13 & 2.69 & 9 \\
\hline Efficient energy forecasts in sustainable buildings & 2.61 & 12 & 2.51 & 9 & 2.49 & 11 & 2.45 & 8 \\
\hline $\begin{array}{c}\text { Improvements in BIM application standards in } \\
\text { sustainable buildings }\end{array}$ & 2.56 & 13 & 2.43 & 11 & 2.32 & 12 & 2.30 & 11 \\
\hline
\end{tabular}


The analysis results show that the top three strategies to use when adopting BIM in sustainable building projects are as follows: "workshops, lectures, and conference events are used to enhance public awareness," "better information on the cost and benefits of sustainable materials," and "strengthened sustainable development." According to the contractors' perspectives, "workshops, lectures, and conference events are used to enhance public awareness" was ranked second, "better information on the cost and benefits of sustainable materials" was ranked first, and "strengthened sustainable development" was ranked third. According to the consultants' perspectives, "workshops, lectures, and conference events are used to enhance public awareness" was also ranked second, "better information on the cost and benefits of sustainable materials" was also ranked first, but "strengthened sustainable development" was ranked fourth.

Furthermore, according to the clients' perspectives, "workshops, lectures, and conference events are used to enhance public awareness" was ranked first, "better information on the cost and benefits of sustainable materials" was ranked third, and "strengthened sustainable development" was ranked second. Therefore, it is worth mentioning that according to the feedback of contractors, clients, and consultants, it was shown that "workshop, lecture, and conference events are used to enhance public awareness," "better information on the cost and benefits of sustainable materials," and "strengthened sustainable development" were the most common strategies. Although the ranking varied, these strategies gained attention from contractors, clients, and consultants.

\subsection{Exploratory Factor Analysis (EFA)}

Exploratory factor analysis (EFA) is a technique that aids in the identification of the common factor among multiple variables that support or underpin the items in a given collection. The KMO value of this study was 0.519 , which was acceptable as it satisfied the threshold of 0.50 . Table 4 illustrates the clear picture of EFA analysis and comprises four groups: (i) standardization-related strategy, (ii) economic-related strategy, (iii) awarenessrelated strategy, and (iv) environment-related strategy.

Table 4. Results of the EFA analysis.

\begin{tabular}{|c|c|c|c|c|c|}
\hline Strategies & 1 & 2 & 3 & 4 & Grouping \\
\hline \multirow{3}{*}{$\begin{array}{l}\text { Prompting construction industry standards } \\
\text { Improvements in BIM application standards in } \\
\text { sustainable buildings } \\
\text { Compel strict environmental controls } \\
\text { and assessments }\end{array}$} & 0.873 & & & & \multirow{3}{*}{$\begin{array}{l}\text { Standardization-related } \\
\text { strategy }\end{array}$} \\
\hline & 0.865 & - & - & - & \\
\hline & 0.833 & & & & \\
\hline $\begin{array}{l}\text { Economic and additional financial BIM } \\
\text { adoption rewards }\end{array}$ & \multirow[t]{2}{*}{ - } & 0.821 & - & - & \multirow{2}{*}{ Economic-related strategy } \\
\hline $\begin{array}{l}\text { Better information on the costs and benefits of } \\
\text { sustainable materials }\end{array}$ & & 0.819 & & & \\
\hline $\begin{array}{l}\text { Enhance social networking (e.g., print media, } \\
\text { internet, and radio and television programs) }\end{array}$ & \multirow{5}{*}{-} & & 0.765 & & \multirow{5}{*}{$\begin{array}{l}\text { Awareness-related } \\
\text { strategy }\end{array}$} \\
\hline $\begin{array}{l}\text { More research on BIM toward } \\
\text { sustainable buildings }\end{array}$ & & - & 0.759 & - & \\
\hline $\begin{array}{c}\text { Workshop, lecture, and conference events are } \\
\text { used to enhance public awareness }\end{array}$ & & & 0.751 & & \\
\hline Overall support from the senior management & & & 0.740 & & \\
\hline Acknowledging and supporting BIM experts & & & 0.732 & & \\
\hline $\begin{array}{l}\text { System of green or environmentally } \\
\text { friendly labeling }\end{array}$ & \multirow{3}{*}{-} & & & 0.690 & \multirow{3}{*}{$\begin{array}{l}\text { Environment-related } \\
\text { strategy }\end{array}$} \\
\hline $\begin{array}{l}\text { Efficient energy forecasts in } \\
\text { sustainable buildings }\end{array}$ & & - & & 0.621 & \\
\hline Strengthened sustainable development & & & & 0.615 & \\
\hline
\end{tabular}




\section{Discussion}

This section addresses the top three strategies for adopting BIM in sustainable building projects in depth based on the mean score analysis and group formation by EFA.

\subsection{Discussion Based on the Mean Score Analysis}

5.1.1. Workshop, Lecture, and Conference Events Are Used to Enhance Public Awareness

In Malaysia, there is still a lack of understanding about the benefits of using BIM. When a company uses BIM in its daily operations, the level of BIM acceptance and team awareness increases, and teaching or facilitating seminars become passive if they are not used. Willingness and dedication both contribute to its successful adaptation, and participation in the development of BIM strategies aids in keeping team members and colleagues actively involved in the project. The implementation of workshops, lectures, and conference events to discuss the need for the construction industry to incorporate sustainability in building projects is crucial. Professional bodies have an important obligation to organize workshops, lectures, and conference events related to the use of BIM in sustainable building projects in order to raise awareness of the value of sustainability. The current trend in developing countries toward environmental sustainability has resulted in a huge demand for delivering construction projects, which has exceeded sustainability concerns.

\subsubsection{Better Information on the Costs and Benefits of Sustainable Materials}

The majority of projects fail because the cost estimate significantly underestimates the actual cost of the project. Unfortunately, the bulk of the projects were not completed on time or on budget. Construction projects have received a substantial portion of national investment funds from developing-country governments. Projects in developing countries have a significant economic impact because of their profound effects on climate and socioeconomic systems. Aside from financial considerations, project priorities and building performance are the most important factors in determining construction sustainability. The construction industry contributes to the majority of economic well-being by assisting in the construction of sustainable projects and adding value to building materials [69]. The use of building materials has a significant environmental effect, owing to the vast quantity of non-renewable resources that have the potential to deprive future generations of their use.

\subsubsection{Strengthened Sustainable Development}

Sustainable development provides a new way of thinking that aligns the universal human desire to enhance our quality of life with the constraints placed by our global environment. The adoption of BIM in construction is gaining traction as a means of boosting long-term growth. When considering the built environment, which has an effect on the heart of social-ecological processes, information technology, and natural ecosystems, a wider view of sustainable development is necessary. BIM has historically been used in project- and construction-related fields such as production and design, but there has recently been a surge of interest in the idea of sustainable development.

\subsection{Discussion Based on EFA}

\subsubsection{Standardization-Related Strategy}

The standardization-related strategy consists of "promoting construction industry standards," "improvements in BIM application standards in sustainable buildings," and "compel strict environmental controls and assessments." BIM refers to long-term structures and technologies that enable stakeholders to interact over the life cycle of a project by enabling them to insert, remove, update, or change information in the BIM model. Traditional project application tools produce less accessible data and knowledge for visualizations and simulations than BIM applications. The implementation of BIM software that integrates the model and simulation would expand on previous technological advances to allow for analyzing and processing multiple information streams at the same time, resulting in the elimination of data handling errors. According to Zhang et al. [69], the intelligent 
data generated by the BIM model can be used to conduct whole-building energy analysis, simulate the performance, and visualize the appearance. As this system is integrated into the design, designers will make direct comparisons of the design's results over the life cycle to help ensure that its capabilities and design defects are detected and removed early.

\subsubsection{Economic-Related Strategy}

The economic-related strategy consists of "economic and additional financial BIM adoption rewards" and "better information on the cost and benefits of sustainable materials." Sustainable building projects necessitate a long-term perspective that weighs the initial capital cost against the structure's operating costs. The greatest economic benefits of sustainable construction are seen in terms of lower operating and service costs, as well as operational and maintenance costs, and greater building efficiency, which are mutually beneficial. Since the time required to introduce sustainable practices is clearly insufficient to justify their adoption in a highly competitive market, the long-term costs could be prohibitive. There is a lag in implementing new and more sustainable methods that strive to increase overall performance as long as good practices spread. According to Ayarkwa et al. [70], this lag is mostly due to a lack of client demand, as well as the mistaken belief that sustainable construction methods are more expensive than traditional construction methods. To ensure more competitive options are available, cost consultants should add a $10 \%$ margin to capital costs.

\subsubsection{Awareness-Related Strategy}

The awareness-related strategy consists of "enhance social networking (e.g., print media, internet, and radio and television programs)," "more research on BIM toward sustainable buildings," "workshop, lecture, and conference events are used to enhance public awareness," "overall support from the senior management," and "acknowledging and supporting BIM experts." The Construction Industry Development Board (CIDB) Malaysia, which aims to increase, advance, and promote construction growth while also assisting in making the industry more sustainable, has identified the need for better environmental aspects as one of its main functions. The CIDB Malaysia has organized a number of seminars, dialogues, and forums to resolve and prioritize environmental needs in the construction industry. Other Malaysian institutions that have spearheaded research in this field include the National Institution of Valuation, Malaysia (INSPEN); the Malaysian Science and Technology Information Centre (MASTIC); and local universities [71]. Several government, technical, and non-profit organizations have launched a variety of sustainable application programs for developers to help them gain a better understanding of these concerns and learn how to apply them responsibly. Several seminars, lectures, presentations, workshops, and speeches have been given about the importance of sustainable practices in the construction industry in order to elevate the industry's status as a long-term developer.

\subsubsection{Environment-Related Strategy}

The environment-related strategy consists of "system of green or environmentallyfriendly labelling," "efficient energy forecasts in sustainable buildings" and "strengthened sustainable development." Building professionals all over the world are involved in improving the environment and introducing innovative development technologies that have a lower environmental impact, which has resulted in buildings with recycling and ecolabeling incorporated in their designs. Building efficiency is now a significant concern for building professionals and environmental building performance evaluation has emerged as one of the major concerns in sustainable construction. In 2009, the Board of Architects Malaysia (PAM), in partnership with the Association of Consulting Engineers Malaysia (ACEM), launched the Green Building Index (GBI) Malaysia to guide the Malaysian property industry toward being more environmentally friendly. Through this rating system, developers have an opportunity to create and construct environmentally friendly buildings while reducing energy and water use, reducing air pollution, increasing accessibility 
to public transportation, improving accessibility to community green initiatives, getting people involved in recycling, and beautifying their properties

\subsection{Comparison of Results with the United States and New Zealand}

To this end, this study compared the top three identified strategies for Malaysia, the United States, and New Zealand. This type of outcome comparison has piqued the interest of academics in the field of construction management. Table 5 shows that "workshop, lecture, and conference events are used to enhance public awareness" was the most popular strategy for adopting BIM in sustainable building projects in Malaysia, while ranking ninth in the United States and "not identified" in New Zealand. Furthermore, "better information on the cost and benefits of sustainable materials" was placed second in Malaysia, despite being rated sixth in both the United States and New Zealand. Malaysia ranked the strategy "strengthened sustainable development" in third place, which is comparable to the United States, which ranked it fourth, and New Zealand, which ranked it fifth.

Table 5. Comparison of results with the United States and New Zealand.

\begin{tabular}{cccc}
\hline Top 3 Strategies & $\begin{array}{c}\text { Malaysia } \\
\text { (Current Study) }\end{array}$ & United States [72] & New Zealand [73] \\
\hline $\begin{array}{c}\text { Workshop, lecture, and } \\
\text { conference events are } \\
\text { used to enhance public } \\
\text { awareness }\end{array}$ & Rank 1st & Rank 9th & Not identified \\
\hline $\begin{array}{c}\text { Better information on the } \\
\text { costs and benefits of } \\
\text { sustainable materials }\end{array}$ & Rank 2nd & Rank 6th & Rank 6th \\
\hline $\begin{array}{c}\text { Strengthened sustainable } \\
\text { development }\end{array}$ & Rank 3rd & Rank 4th & Rank 5th \\
\hline
\end{tabular}

\section{Conclusions, Limitation, and Future Directions}

This study's main aim was to analyze how BIM can be used in sustainable buildings in Malaysia. It was found that workshops, lectures, and conference events were used to enhance public awareness. Better information on sustainable materials' costs and benefits and strengthening sustainable development were the topmost essential strategies for boosting sustainable growth in building projects. Based on the EFA analysis, this study classified four groups of strategies: standardization-related strategy, economic-related strategy, awareness-related strategy, and environment-related strategy. In addition, the findings of this study provide a valuable guide for relevant authorities and governments when developing relevant legal norms to enhance the applications of BIM in sustainable buildings; by developing relevant regulations, project participants can clarify the application requirements of BIM technology. Furthermore, BIM users should consider the importance of using BIM technology in the construction of sustainable buildings.

In terms of building design, for practical applications, it is required that facilities management personnel be incorporated into the building development alongside architecture and engineering. This finding provides a foundation for researchers interested in studying the impact of BIM in developing countries, especially in the fields of construction engineering and management. This understanding will boost the perceived satisfaction and increase the desire to use the framework. This study has some limitations. Since this research was conducted in Malaysia, the results may not be valid in other countries due to cultural differences. However, it is recommended that additional research is performed to compare the results. Furthermore, structural equation modeling (SEM) will be needed in the future to gain a thorough understanding of the strategies for implementing BIM in sustainable building projects. 
Author Contributions: Conceptualization, B.M.; investigation, B.M.; data creation, B.M. and S.S.S.G.; writing—original draft, B.M. and I.O.; Supervision, I.O.; investigation, S.S.S.G.; review—editing, E.H.; funding acquisition, E.H. All authors have read and agreed to the published version of the manuscript.

Funding: This research received no external funding.

Institutional Review Board Statement: Not applicable.

Informed Consent Statement: Not applicable.

Conflicts of Interest: The authors declare no conflict of interest.

\section{References}

1. Shaikh, A.H. Malaysia's Public Enterprises: A Performance Evaluation. Asean Econ. Bull. 1992, 9, 207-218. [CrossRef]

2. Stahl, C.W.; Appleyard, R.T. International Manpower Flows in Asia: An Overview. Asian Pac. Migr. J. 1992, 1, 417-476. [CrossRef] [PubMed]

3. Ariffin, A.S. Inculcating Innovation Culture and Developing Strategic Management of Technology and Innovation Plan in SME's for Wealth Creation to support Malaysia National Entrepreneurship Policy 2030. J. Sci. Technol. Innov. Policy $2019,5,10$.

4. Bin Ibrahim, A.R.; Roy, M.H.; Ahmed, Z.; Imtiaz, G. An investigation of the status of the Malaysian construction industry. Benchmarking Int. J. 2010, 17, 294-308. [CrossRef]

5. Li, Z.; Quan, S.J.; Yang, P.P.-J. Energy performance simulation for planning a low carbon neighborhood urban district: A case study in the city of Macau. Habitat Int. 2016, 53, 206-214. [CrossRef]

6. Diaz-Sarachaga, J.M.; Jato-Espino, D.; Castro-Fresno, D. Methodology for the development of a new Sustainable Infrastructure Rating System for Developing Countries (SIRSDEC). Environ. Sci. Policy 2017, 69, 65-72. [CrossRef]

7. Olawumi, T.O.; Chan, D.W. Identifying and prioritizing the benefits of integrating BIM and sustainability practices in construction projects: A Delphi survey of international experts. Sustain. Cities Soc. 2018, 40, 16-27. [CrossRef]

8. Fearnside, P.M. Challenges for sustainable development in Brazilian Amazonia. Sustain. Dev. 2018, 26, 141-149. [CrossRef]

9. Manzoor, B.; Othman, I.; Manzoor, M. Evaluating the critical safety factors causing accidents in high-rise building projects. Ain Shams Eng. J. 2021. [CrossRef]

10. Khan, H.H.; Malik, M.N.; Zafar, R.; Goni, F.A.; Chofreh, A.G.; Klemeš, J.J.; Alotaibi, Y. Challenges for sustainable smart city development: A conceptual framework. Sustain. Dev. 2020, 28, 1507-1518. [CrossRef]

11. WCED. Special Working Session World commission on environment and development. Our. Common. Futur. 1987, 17, 1-91.

12. Oh, T.H.; Hasanuzzaman, M.; Selvaraj, J.; Teo, S.C.; Chua, S.C. Energy policy and alternative energy in Malaysia: Issues and challenges for sustainable growth-An update. Renew. Sustain. Energy Rev. 2018, 81, 3021-3031. [CrossRef]

13. Prizeman, O.; Pezzica, C.; Taher, A.; Boughanmi, M. Networking Historic Environmental Standards to Address Modern Challenges for Sustainable Conservation in HBIM. Appl. Sci. 2020, 10, 1283. [CrossRef]

14. Pan, S.-Y.; Gao, M.; Kim, H.; Shah, K.; Pei, S.-L.; Chiang, P.-C. Advances and challenges in sustainable tourism toward a green economy. Sci. Total. Environ. 2018, 635, 452-469. [CrossRef]

15. Banihashemi, S.; Hosseini, M.R.; Golizadeh, H.; Sankaran, S. Critical success factors (CSFs) for integration of sustainability into construction project management practices in developing countries. Int. J. Proj. Manag. 2017, 35, 1103-1119. [CrossRef]

16. Abolore, A.A. Comparative study of environmental sustainability in building construction in Nigeria and Malaysia. J. Emerg. Trends Econ. Manag. Sci. 2012, 3, 951-961.

17. Jamaludin, S.Z.H.S.; A. Mahayuddin, S.; A. Hamid, S.H. Challenges of Integrating Affordable and Sustainable Housing in Malaysia. In IOP Conference Series: Earth and Environmental Science; IOP Publishing: Bristol, UK, 2018; Volume 140, p. 012001.

18. Durdyev, S.; Ismail, S.; Ihtiyar, A.; Abu Bakar, N.F.S.; Darko, A. A partial least squares structural equation modeling (PLS-SEM) of barriers to sustainable construction in Malaysia. J. Clean. Prod. 2018, 204, 564-572. [CrossRef]

19. Karakhan, A.A.; Gambatese, J.; Simmons, D.R.; Nnaji, C. How to improve workforce development and sustainability in construction. In Construction Research Congress 2020: Safety, Workforce, and Education; American Society of Civil Engineers Reston: Reston, VA, USA, 2020; pp. 21-30.

20. Yap, J.B.H.; Ni Chow, I.; Shavarebi, K. Criticality of Construction Industry Problems in Developing Countries: Analyzing Malaysian Projects. J. Manag. Eng. 2019, 35, 04019020. [CrossRef]

21. Saieg, P.; Sotelino, E.D.; Nascimento, D.; Caiado, R. Interactions of Building Information Modeling, Lean and Sustainability on the Architectural, Engineering and Construction industry: A systematic review. J. Clean. Prod. 2018, 174, 788-806. [CrossRef]

22. Darko, A.; Zhang, C.; Chan, A.P. Drivers for green building: A review of empirical studies. Habitat Int. 2017, 60, 34-49. [CrossRef]

23. Ahmad, T.; Aibinu, A.A.; Stephan, A. Managing green building development-A review of current state of research and future directions. Build. Environ. 2019, 155, 83-104. [CrossRef]

24. Ge, J.; Luo, X.; Hu, J.; Chen, S. Life cycle energy analysis of museum buildings: A case study of museums in Hangzhou. Energy Build. 2015, 109, 127-134. [CrossRef]

25. Chen, L.; Luo, H. A BIM-based construction quality management model and its applications. Autom. Constr. 2014, 46, 64-73. [CrossRef] 
26. Islam, H.; Jollands, M.; Setunge, S.; Haque, N.; Bhuiyan, M.A. Life cycle assessment and life cycle cost implications for roofing and floor designs in residential buildings. Energy Build. 2015, 104, 250-263. [CrossRef]

27. Straub, A. Estimating the Service Lives of Building Products in Use. J. Civ. Eng. Arch. 2015, 9, 2015. [CrossRef]

28. Verbeeck, G.; Henß, H. Life cycle inventory of buildings: A calculation method. Build. Environ. 2010, 45, 1037-1041. [CrossRef]

29. Curry, E.; O’Donnell, J.; Hasan, S.; Keane, M.; O’Riain, S. Linking building data in the cloud: Integrating cross-domain building data using linked data. Adv. Eng. Inform. 2013, 27, 206-219. [CrossRef]

30. Bynum, P.; Issa, R.R.A.; Olbina, S. Building Information Modeling in Support of Sustainable Design and Construction. J. Constr. Eng. Manag. 2013, 139, 24-34. [CrossRef]

31. Kota, S.; Haberl, J.S.; Clayton, M.J.; Yan, W. Building Information Modeling (BIM)-based daylighting simulation and analysis. Energy Build. 2014, 81, 391-403. [CrossRef]

32. Gassar, A.A.A.; Cha, S.H. Energy prediction techniques for large-scale buildings towards a sustainable built environment: A review. Energy Build. 2020, 224, 110238. [CrossRef]

33. Zou, Z.; Liu, Y.; Ahmad, N.; Sial, M.; Badulescu, A.; Zia-Ud-Din, M.; Badulescu, D. What Prompts Small and Medium Enterprises to Implement CSR? A Qualitative Insight from an Emerging Economy. Sustainability 2021, 13, 952. [CrossRef]

34. Valdes-Vasquez, R.; Klotz, L.E. Social Sustainability Considerations during Planning and Design: Framework of Processes for Construction Projects. J. Constr. Eng. Manag. 2013, 139, 80-89. [CrossRef]

35. Carvajal-Arango, D.; Bahamón-Jaramillo, S.; Aristizábal-Monsalve, P.; Vásquez-Hernández, A.; Botero, L.F.B. Relationships between lean and sustainable construction: Positive impacts of lean practices over sustainability during construction phase. J. Clean. Prod. 2019, 234, 1322-1337. [CrossRef]

36. Munaro, M.R.; Tavares, S.F.; Bragança, L. Towards circular and more sustainable buildings: A systematic literature review on the circular economy in the built environment. J. Clean. Prod. 2020, 260, 121134. [CrossRef]

37. Kemp, R.; Parto, S.; Gibson, R.B. Governance for sustainable development: Moving from theory to practice. Int. J. Sustain. Dev. 2005, 8, 12. [CrossRef]

38. Cuthill, M. Strengthening the 'social' in sustainable development: Developing a conceptual framework for social sustainability in a rapid urban growth region in Australia. Sustain. Dev. 2010, 18, 362-373. [CrossRef]

39. Berchin, I.I.; Sima, M.; De Lima, M.A.; Biesel, S.; Dos Santos, L.P.; Ferreira, R.V.; Guerra, J.B.S.O.D.A.; Ceci, F. The importance of international conferences on sustainable development as higher education institutions' strategies to promote sustainability: A case study in Brazil. J. Clean. Prod. 2018, 171, 756-772. [CrossRef]

40. Filho, W.L.; Shiel, C.; Paço, A.; Mifsud, M.; Ávila, L.V.; Brandli, L.L.; Molthan-Hill, P.; Pace, P.; Azeiteiro, U.M.; Vargas, V.R.; et al. Sustainable Development Goals and sustainability teaching at universities: Falling behind or getting ahead of the pack? J. Clean. Prod. 2019, 232, 285-294. [CrossRef]

41. Caiado, R.G.G.; Quelhas, O.L.G.; Nascimento, D.L.D.M.; Anholon, R.; Filho, W.L. Towards sustainability by aligning operational programmes and sustainable performance measures. Prod. Plan. Control. 2019, 30, 413-425. [CrossRef]

42. Presley, A.; Meade, L. Benchmarking for sustainability: An application to the sustainable construction industry. Benchmarking Int. J. 2010, 17, 435-451. [CrossRef]

43. Sarkar, O.; Katakojwala, R.; Mohan, S.V. Low carbon hydrogen production from a waste-based biorefinery system and environmental sustainability assessment. Green Chem. 2021, 23, 561-574. [CrossRef]

44. Tushar, Q.; Bhuiyan, M.A.; Zhang, G.; Maqsood, T. An integrated approach of BIM-enabled LCA and energy simulation: The optimized solution towards sustainable development. J. Clean. Prod. 2021, 289, 125622. [CrossRef]

45. Wong, K.; Fan, Q. Building information modelling (BIM) for sustainable building design. Facilities 2013, 31, 138-157. [CrossRef]

46. Santos, R.; Costa, A.A.; Grilo, A. Bibliometric analysis and review of Building Information Modelling literature published between 2005 and 2015. Autom. Constr. 2017, 80, 118-136. [CrossRef]

47. Yudelson, J. Green Building A to Z: Understanding the Language of Green Building; New Society Publishers: London, UK, 2007.

48. Son, H.; Kim, C.; Chong, W.K.; Chou, J.-S. Implementing sustainable development in the construction industry: Constructors' perspectives in the US and Korea. Sustain. Dev. 2009, 19, 337-347. [CrossRef]

49. Ahmad, T.; Thaheem, M.J.; Anwar, A. Developing a green-building design approach by selective use of systems and techniques. Arch. Eng. Des. Manag. 2016, 12, 29-50. [CrossRef]

50. Hwang, B.G.; Tan, J.S. Green building project management: Obstacles and solutions for sustainable development. Sustain. Dev. 2010, 20, 335-349. [CrossRef]

51. Salam, M.A. An empirical investigation of the determinants of adoption of green procurement for successful green supply chain management. In Proceedings of the 2008 4th IEEE International Conference on Management of Innovation and Technology, Bangkok, Thailand, 21-24 September 2008; pp. 1038-1043.

52. Qian, Q.K.; Chan, E.H.W. Government measures for promoting Building Energy Efficiency (BEE): A comparative study between China and some developed countries. In Proceedings of the 12th International Research Symposium on Advancement of Construction Management and Real Estate (CRIOCM 2007), Sydney, NSW, Australia, 8-10 August 2007; pp. 51-56.

53. Qian, Q.K.; Fan, K.; Chan, E.H.W. Regulatory incentives for green buildings: Gross floor area concessions. Build. Res. Inf. 2016, 44, 675-693. [CrossRef]

54. Häkkinen, T.; Belloni, K. Barriers and drivers for sustainable building. Build. Res. Inf. 2011, 39, 239-255. [CrossRef] 
55. Manzoor, B.; Othman, I. Safety Management Model During Construction Focusing on Building Information Modeling (BIM). Lect. Notes Civ. Eng. 2021, 31-37. [CrossRef]

56. Qureshi, A.H.; Alaloul, W.S.; Manzoor, B.; Musarat, M.A.; Saad, S.; Ammad, S. Implications of machine learning integrated technologies for construction progress detection under industry 4.0 (IR 4.0). In Proceedings of the 2020 Second International Sustainability and Resilience Conference: Technology and Innovation in Building Designs (51154), Sakheer, Bahrain, 11-12 November 2020; IEEE: Piscataway, NJ, USA, 2021; pp. 1-6.

57. Shi, Q.; Zuo, J.; Huang, R.; Huang, J.; Pullen, S. Identifying the critical factors for green construction-An empirical study in China. Habitat Int. 2013, 40,1-8. [CrossRef]

58. Construction, M.-H. The business value of BIM in North America: Multi-year trend analysis and user ratings (2007-2012). In Proceedings of the AIA AAJ National Conference, Portland, OR, USA, 18-21 September 2012.

59. NBS. NBS, National BIM Report 2017; RIBA Ent. Ltd.: London, UK, 2017.

60. Wang, G.; Song, J. The relation of perceived benefits and organizational supports to user satisfaction with building information model (BIM). Comput. Hum. Behav. 2017, 68, 493-500. [CrossRef]

61. Cao, D.; Li, H.; Wang, G. Impacts of Isomorphic Pressures on BIM Adoption in Construction Projects. J. Constr. Eng. Manag. 2014, 140, 04014056. [CrossRef]

62. Röck, M.; Hollberg, A.; Habert, G.; Passer, A. LCA and BIM: Visualization of environmental potentials in building construction at early design stages. Build. Environ. 2018, 140, 153-161. [CrossRef]

63. Chastas, P.; Theodosiou, T.; Bikas, D. Embodied energy in residential buildings-towards the nearly zero energy building: A literature review. Build. Environ. 2016, 105, 267-282. [CrossRef]

64. Motuzienè, V.; Rogoža, A.V.; Lapinskienè, T. Vilutienè, Construction solutions for energy efficient single-family house based on its life cycle multi-criteria analysis: A case study. J. Clean. Prod. 2016, 112, 532-541. [CrossRef]

65. Pallant, J.; Manual, S.S. A step by step guide to data analysis using SPSS for windows. In SPSS Survival Manual; Open University Press: New York, NY, USA, 2007.

66. Gauthier, T. Detecting Trends Using Spearman's Rank Correlation Coefficient. Environ. Forensics 2001, 2, 359-362. [CrossRef]

67. Chan, A.P.C.; Darko, A.; Olanipekun, A.O.; Ameyaw, E.E. Critical barriers to green building technologies adoption in developing countries: The case of Ghana. J. Clean. Prod. 2018, 172, 1067-1079. [CrossRef]

68. Darko, A.; Chan, A.P.C. Strategies to promote green building technologies adoption in developing countries: The case of Ghana. Build. Environ. 2018, 130, 74-84. [CrossRef]

69. Zhang, R.; Tang, Y.; Wang, L.; Wang, Z. Factors Influencing BIM Adoption for Construction Enterprises in China. Adv. Civ. Eng. 2020, 2020, 8848965. [CrossRef]

70. Ayarkwa, J.; Acheampong, A.; Wiafe, F.; Boateng, B.E. Factors affecting the implementation of sustainable construction in Ghana: The architect's perspective. In Proceedings of the ICIDA 2017-6th International Conference on Infrastructure Development in Africa, Kumasi, Ghana, 12-14 April 2017; pp. 12-14.

71. Abidin, N.Z. Sustainable practices in Malaysia: Are we ready for it? In Proceedings of the Global Conference on Global Warming 2008 (GCGW-08), Istanbul, Turkey, 30 September 2008.

72. Darko, A.; Chan, A.P.C.; Ameyaw, E.E.; He, B.-J.; Olanipekun, A.O. Examining issues influencing green building technologies adoption: The United States green building experts' perspectives. Energy Build. 2017, 144, 320-332. [CrossRef]

73. Doan, D.T.; GhaffarianHoseini, A.; Naismith, N.; GhaffarianHoseini, A.; Zhang, T.; Tookey, J. Examining critical perspectives on Building Information Modelling (BIM) adoption in New Zealand. Smart Sustain. Built Environ. 2020. [CrossRef] 